\title{
UTILIZATION OF DIFFERENT SOIL SINKAGE PLATES TO PREDICT TIRE INFLATION PRESSURE AND ITS SINKAGE UNDER DIFFERENT SOIL CONDITIONS.
}

\author{
Bahnasy, A.M.F
}

\begin{abstract}
This paper presents an algorithm for adapting the tire inflation pressure of off road vehicles operating on rough terrain to reach tire floatation. The algorithm accounts for dynamic effects of tire sinkage and tire deflection in the vehicle/terrain interaction. Extensive simulation and experimental results demonstrate the method effectiveness. In order to evaluate the variability of sinkage measurements using three different shapes (rectangular, ellipse and circular plates) on a uniformly prepared sand soil with three different bulk densities of 1200, 1270 and $1315 \mathrm{~kg}$. $m^{-3}$ and three different moisture contents, a set of three plates having dimensions of (34*85), (45*64) and (40*61.6) mm for rectangular plates, (40*97), (37*92) and (33*52) for ellipse plates, 27.5, 26.7 and $30 \mathrm{~mm}$ radius for circle plates were tested for pressure vs sinkage results five times each in four test series. From the individual plate sinkage vs. pressure results, the constants $k_{c}, k_{\varphi}$ and $n$ in Bekker's sinkage equation were evaluated using groups of three plates and a least squares best fit procedure. The instrumentation of the sinkage device and the measurements of the response of sand to normal loading in laboratory conditions are presented. The sinkage tests were conducted by means of static weight driven loading equipment. The vertical plate sinkage and the load applied to the plate were measured. From the experimental data, the sinkage parameters $k_{c}, k_{\phi}$ and $n$ in Bekker pressure-sinkage equation could be derived. The results showed that the used experimental device was suitable for identifying the soil sinkage parameters in relation to offroad mobility. The purpose of this study is to estimate the proper tire inflation pressure according to soil conditions. The soil conditions are varied from hard to soft as soil bulk density and soil moisture are
\end{abstract}

-Senior Researcher, Agric. Eng. Res. Inst. Dokki Giza 
changed the results showed that the constants $k_{c}, k_{\varphi}$ and $n$ are changed as soil moisture and bulk density change. The highest value for $k_{c}$ and $k_{\varphi}$ were found at the lower soil moisture content and bulk density. Values of exponent $n$ ranged from 1 to 1.53 according to soil condition and sinkage plate shape. The constants in Bekker's sinkage equation derived from rectangle and ellipse shape are very closed each other than they get from the circle sinkage shape.

\section{INTRODUCTION}

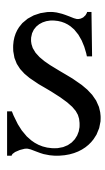
oil physical properties are highly affected by soil compaction. The weight from tractors and agricultural machines compacted the soil to the point of reducing productivity. The term compaction refers to the act of artificially increasing the density of soil. It involves the pressing of soil particles together into closer contact, and expelling air or water from spaces between them. As a result the worst soil physical properties are expected. Soil may be compacted by pressure, vibration, impact or by combinations resulting from tractors traffic. Several studies have conducted to determine the effect of tire inflation pressure on soil physical properties.

Reece (1964) drive the least squares method in fitting of pressure-sinkage data to calculate bekker equation constants

$$
\begin{aligned}
& k_{c}=\frac{\Sigma\left(\frac{k}{b}\right)-\Sigma k\left(\frac{1}{b}\right) / M}{\Sigma\left(\frac{1}{b}\right)^{2}-\left(\Sigma\left(\frac{1}{b}\right)\right)^{2} / M} \\
& \mathrm{k}_{\varphi}=\left(\Sigma \mathrm{k}^{2}-\mathrm{k}_{\mathrm{c}} \Sigma\left(\frac{1}{\mathrm{~b}}\right)\right) / \mathrm{M} \\
& \mathrm{n}=\frac{\Sigma(\operatorname{lnz} \ln \mathrm{p})-(\Sigma \ln \mathrm{z} \Sigma \ln \mathrm{p}) / \mathrm{M}}{\Sigma(\operatorname{lnz})^{2}-(\Sigma \ln \mathrm{z})^{2} / \mathrm{M}}
\end{aligned}
$$

Where:-

$\mathrm{P}=$ vertical average contact pressure, $\mathrm{kPa}$,

$\mathrm{k}_{\mathrm{c}}=$ modules of cohesion $\mathrm{kN} / \mathrm{m}^{\mathrm{n}+1}$

$\mathrm{k}_{\phi}=$ friction moduli of deformation, $\mathrm{kN} / \mathrm{m}^{\mathrm{n}+2}$ 
$\mathrm{b}=$ the a smaller dimension of the loading area, $\mathrm{m}$

$\mathrm{z}=$ depth of sinkage, $\mathrm{m}$,

$\mathrm{n}=\mathrm{a}$ soil constant related to the soil characteristics, nondimensional

$\mathrm{M}=$ number of data points used in the fitting $\mathrm{k}=\left(\frac{k_{c}}{b}+k_{\varphi}\right)$

Pope (1969) showed that the rate of sinkage is an important factor in that relationship and suggestions of development studies were done in order to find a correlation between soil resistance and sinkage rate.

A basic equation, developed at the beginning of the last century (eq.4) shows that penetration of the element pressed into the soil $\mathrm{Z}$ depend on its pressure per unit area $\mathrm{p}$, the modulus of soil rigidity $\mathrm{k}$, and the soil state (moisture, cohesion, density) expressed by a dimensionless exponent $\mathrm{n}$ (McKyes 1985).

$$
P=k Z^{n}
$$

Maclaurin (1990) investigate that the sinkage model for a wheel pass

$$
Z=d .\left(\frac{0.224}{N_{c i}^{1.25}}\right)
$$

Where:

$$
\begin{aligned}
& \mathrm{Z}=\text { Tire sinkage, } \mathrm{m} \\
& \mathrm{N}_{\mathrm{ci}}=\text { vehicle mobility, dimensionless. } \\
& \mathrm{d}=\text { Tire diameter, } \mathrm{m}
\end{aligned}
$$

Lee and Kim (1977) gave a model for optimizing the tire inflation pressure $\left(\mathrm{P}_{\mathrm{i}}\right)$ as follow;

$$
\begin{gathered}
\mathrm{Pi}=98.1\left(\frac{\mathrm{W}}{58 * \mathrm{~kb}^{1.39}\left(d_{R I M}+b^{\prime}\right)}\right)^{1.71} \\
b^{\prime}=\frac{b}{143.3}\left[180-\sin ^{-1}\left(\frac{b_{R I M}}{b}\right) * \frac{180}{\pi}\right]
\end{gathered}
$$


Where:

$$
\begin{aligned}
& \mathrm{W}=\text { vertical weight, } \mathrm{kN} \\
& \mathrm{d}_{\mathrm{RIM}}=\text { Rim diameter, } \mathrm{m} \\
& \mathrm{b}_{\mathrm{RIM}}=\text { Rim width, } \mathrm{m} \\
& \mathrm{k}=\left(\frac{k_{c}}{b}+k_{\varphi}\right) \\
& \mathrm{k}_{\mathrm{c}}=\text { modules of cohesion } \mathrm{kN} / \mathrm{m}^{\mathrm{n}+1} \\
& \mathrm{k}_{\phi}=\text { friction moduli of deformation, } \mathrm{kN} / \mathrm{m}^{\mathrm{n}+2}
\end{aligned}
$$

The rate of soil depth change is equal to or correlated with wheel sinkage. Based on the rigid wheel theory, the rolling resistance coefficient $\left(\mu_{R}\right)$ depends on the wheel sinkage $(Z)$ and diameter $(d)$ (Kaje 1968, Gee-Clough 1979) as;

$$
\mu_{\mathrm{R}}==\sqrt{\frac{\mathrm{Z}}{\mathrm{d}}}
$$

If, as assumed, the rut depth is equal to or (linearly) correlated with sinkage then the following model for rut depth $\left(Z_{\text {RUT }}\right)$ can be written,

$$
\mathrm{Z}_{\mathrm{RUT}}=\mu_{\mathrm{R}}^{2} \mathrm{X}
$$

where $\mathrm{x}$ is an empirical scale factor.

There is a large number of mobility studies based on the WES-method, Waterways Experimentation Station, (Saarilahti 1997a). In the simplest model the rolling resistance coefficient can be estimated based on wheel numeric $\left(\mathrm{C}_{\mathrm{N}}\right.$ or $\left.\mathrm{N}_{\mathrm{CI}}\right)$ and empirical constants a and b Eq(10), (Wismer \& Luth 1973, Maclaurin 1990). Constant a represents the $\frac{\mathrm{b}}{\mathrm{N}_{\mathrm{ci}}}$ component of the rolling resistance due to tire deformation, and factor depends on the resistance due to soil deformation.

$$
\mu_{\mathrm{R}}=\mathrm{a}+\frac{\mathrm{b}}{\left[\mathrm{N}_{\mathrm{c}} ; \mathrm{N}_{\mathrm{ci}}\right]}
$$

By combining equations (8) and (10), the following rut depth model (Eq,(11)) can be developed. This means that rut depth can be predicted using the WES-principle. 


$$
\mathrm{Z}_{\mathrm{RUT}}=\mathrm{d} \cdot\left(\mathrm{a}+\frac{\mathrm{b}}{\mathrm{N}_{\mathrm{C}} ; \mathrm{N}_{\mathrm{ci}}}\right)^{2}
$$

Wong (2001) stated that Reece formula is valid for homogeneous terrain. Bekker's pressure sinkage relationship and Reece's modification are independent of the sinkage rate.

Soil compaction is a process through which pore spaces are decreased. It alters the structure of cultivated soil, i.e, the spatial arrangement, size and the shape of clods ans aggregates and consequently the pore spaces inside and between these units (Defossez and Richard 2002). Soil compaction under tractors and farm machinery is of special concern because weights of these machines have been increased dramatically in the last decades and these implements create persistent subsoil compaction (Abu-Hamdeh and Reeder 2003).

Brooks and Iagnemma (2005) suggested a vibration-based terrain classification as a novel sensing mode for identifying terrain class according to load-bearing surfaces that lie below a thin terrain layer of different composition. A good experimental classification results is obtained using even a simple classification algorithm.

Bahnasy (2004) showed that when determining rolling resistance of 2WD tractor, the Bekker's model based on using rectangular plate to determine soil parameters $\mathrm{k}_{\mathrm{c}}, \mathrm{k}_{\varphi}$ and $\mathrm{n}$ was the closest on to the field experiment for the different soil types.

Botero et al. (2005) used $\mathrm{k}_{\mathrm{c}}$ (soil cohesive modulus), $\mathrm{k}_{\varphi}$ (soil friction modulus) and $\mathrm{n}$ of Bekker's equation to get the friction coefficient between the terrain and the tire. However, investigations of Bekker (1960 and 1969) showed that the modulus of rigidity $\mathrm{k}$ significantly depends on dimensions of the element acting upon soil, especially on its width. Therefore, he modified the equation 11 introducing width of the acting element $b$, and two moduli of deformation $\left(\mathrm{k}_{\mathrm{c}}\right.$ and $\left.\mathrm{k}_{\varphi}\right)$, thus separating the effect of cohesion (c) from the effect of internal friction angle $(\varphi)$. This way, the equation 2 was developed 


$$
\begin{gathered}
P=\left(\frac{k_{c}}{b}+k_{\varphi}\right) Z^{n} \\
Z=\left[\frac{P}{K_{d_{b}}+K_{\varphi}}\right]^{\frac{1}{n}}
\end{gathered}
$$

where:

$\mathrm{P}=$ vertical average contact pressure, $\mathrm{kPa}$,

$\mathrm{k}_{\mathrm{c}}=$ modules of cohesion $\mathrm{kN} / \mathrm{m}^{\mathrm{n}+1}$

$\mathrm{k}_{\phi}=$ friction moduli of deformation, $\mathrm{kN} / \mathrm{m}^{\mathrm{n}+2}$

$\mathrm{b}=$ the a smaller dimension of the loading area, $\mathrm{m}$

$\mathrm{z}=$ depth of sinkage, $\mathrm{m}$,

$\mathrm{n}=$ soil constant related to the soil characteristics, nondimensional

Benoit and Gotteland (2006) proposed a new model for vehicle mobility $\left(\mathrm{N}_{\mathrm{ci}}\right)$ and he developed an equation with four model parameters. Comparisons against Bekker's equation and experimental analysis showed that the model was good enough and more adequate to use when only two plates are used in the test.

The soil physical and mechanical properties and soil dynamics properties have significant influences on the amount of energy required for tillage operation (Zadek 2006). The mechanical properties can be categorized as soil physical properties and soil strength parameter (Yu, 2006).

Rashidi,et al.(2006) derived a regression model to calculate the constants $\mathrm{k}_{\mathrm{c}}$ and $\mathrm{k}_{\varphi}$, using three different rectangular plates with different aspect ratios similar to those of pneumatic agricultural tires. It could be very useful to determine the behavioure of tires and tracks of tractors and agricultural machines in the laboratory condition without going to the field.

Mohamed (2007) developed statistical models to predict Bekker's soil parameters $(\mathrm{kc}, \mathrm{k} \phi$, and $\mathrm{n})$, using multiple regression analysis as a 
function of soil cohesion, internal friction angle, cone index and soil texture index to predict $2 \mathrm{WD}$ tractor rolling resistance with low absolute relative error compared to measured values.

The objectives of this study were:

- To determine parameters $\mathrm{kc}, \mathrm{k} \varphi$, and $\mathrm{n}$ in Bekker's equationfor the investigated sandy soil under different soil conditions.

- To determine proper tire inflation pressure for the investigated sandy soil for every condition under test.

- To find out the shape of contact area for sandy soil.

\section{MATRIAL AND METHOD}

\section{MATRIAL}

Laboratory experiments were carried out in the tractor test station, ElSabahia Alexandria Governorate to predict tire inflation pressure and its sinkage under different soil conditions.

\section{Soil texture:}

The soil type which was used in this study is sandy soil from postan Behera. sandy soil was mechanically analyzed as shown in Table (1).

Table (1): Soil mechanical analysis

\begin{tabular}{|l|c|c|c|}
\hline Soil texture & Sand & \multicolumn{1}{|l|}{ Silt } & Clay \\
\hline Sandy & $95.36 \%$ & $2.91 \%$ & $1.73 \%$ \\
\hline
\end{tabular}

\section{Tractor}

A technical specification of the tractor diesel engine is a 2-cylinder, Helwan 35-IMT of maximum power $26.12 \mathrm{~kW}$ at $2200 \mathrm{rpm}$. The bore $\mathrm{x}$ stroke is $105 \mathrm{~mm} \times 125 \mathrm{~mm}$, where the compression ratio is $16: 1$, engine rated speed $1800 \mathrm{rpm}$. Tire dimensions are $0.39 \mathrm{~m}$ width, $1.53 \mathrm{~m}$ diameter and $0.39 \mathrm{~m}$ section height.

\section{Sinkage device}

The sinkage tests were conducted to determine $\mathrm{k}_{\mathrm{c}}, \mathrm{k}_{\phi}$ and $\mathrm{n}$ by applying the principle of constant penetration rate to the sinking of the plates into 
the soil samples. The plate sinkage and the force applied to the plate were measured. The pressure applying at the contact between soil and plate surface was deduced from the measured force and the plate area. The sinkage device consists of a load balance of $(60 \mathrm{~kg}) 0.588 \mathrm{kN}$ capacity (Fig. 1a), sinkage plate is connected to the load balance by a rigid rod allowing a maximum sinkage of $30 \mathrm{~mm}$. The sinkage tests were performed using three circular plates with radius of $26.76,27.5,30 \mathrm{~mm}$, three rectangular plates of $(34 * 85),\left(45^{*} 65\right)$ and $(40 * 61.6) \mathrm{mm}$ three ellipse of $(40 * 97),(37 * 92)$ and $(33 * 52) \mathrm{mm}$. the plate sinkage shape shown in (Fig. 1b). The plates were chosen with respect to the width of the soil bins since previous experimental data indicated that a ratio of soil sample width to sinkage. Since the plate form has strong effect upon the values of sinkage parameters, and consequently upon plate sinkage prediction, four sets of each plates shape having different aspect ratios were also used in order to verify how accurately the sinkage of these plates could be predicted from the results of the three size of different plate shapes. Although the sizes of used plates were small in loose homogeneous sandy samples, all plates deformed the sand with the same patterns so-called local shear failure (Bekker, 1960). Therefore, such small plate sizes have sinkage measurements using three different shapes (rectangular, ellipse and circular plates on a uniformly prepared Sand soil with three different bulk densities of 1200,1270 and $1315{\mathrm{~kg} . ~ \mathrm{~m}^{-3}}^{-3}$ and three different moisture contents of 18, 20 and $25 \%$.

\section{Methods}

\section{Experimental procedure}

To characterize the quasi-static pressure-sinkage relationship of sandy soil, each plate was moved vertically downwards into the soils through soil by means of the static load. Measurements plate sinkage and load applied were recorded the pressure at contact surface between sand and sinkage plate was deduced from the measured normal loads and the plate area to obtain pressure-sinkage curves. 


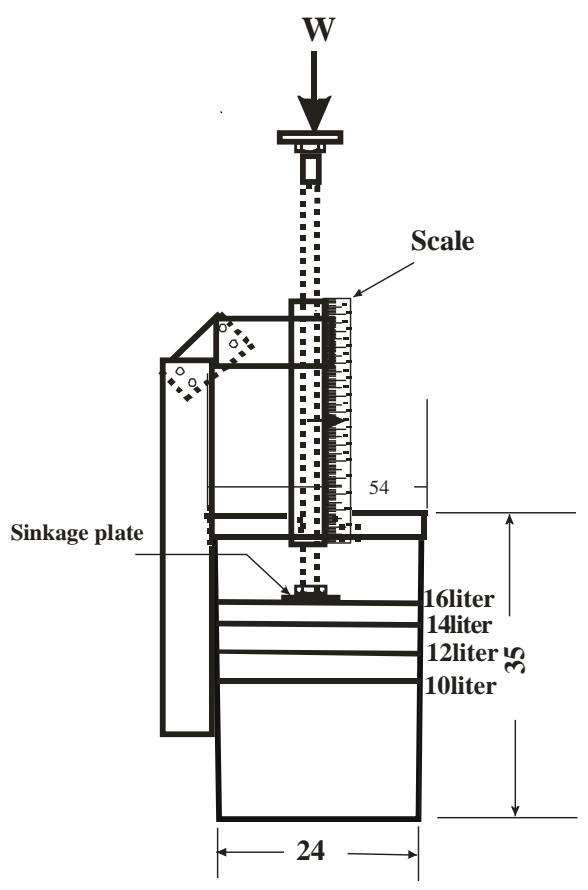

Fig.(1a): The sinkage device
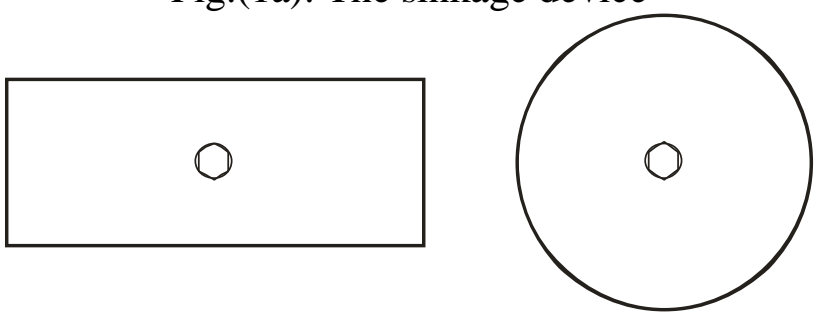

Rectangular plate Circular plate

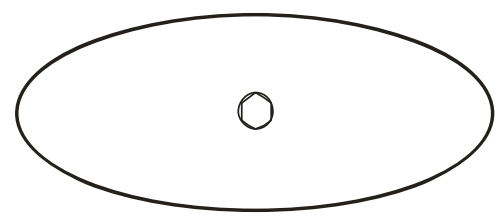

Ellipse plate

Fig. (1b): Sinkage plate shapes 


\section{Determination of $\mathbf{k}_{\mathfrak{c}}, \mathbf{k}_{\phi}$ and $\mathbf{n}$ values}

It was found that the values $\mathrm{k}_{\mathrm{c}}, \mathrm{k}_{\phi}$ and $\mathrm{n}$ were different among rectangular plates of low aspect ratio, and the circular plates, but the difference is practically negligible between rectangular plates of high aspect ratio. In predicting off-road vehicle performance at a given location, the soil parameters might be determined in the most critical conditions expected from the field. Laboratory reproducibility of sandy soil with low soil mass and low moisture content seems to reproduce easily its original condition. In this laboratory bin, dry sand was used in order to obtain homogeneous soil samples of repeatable conditions. The texture of the sand is given in Table 1. The sand samples were prepared in homogeneous one-layer configuration with desired bulk density in small bins having the same base of $240 \mathrm{~mm}$ x $540 \mathrm{~mm}$ and $350 \mathrm{~mm}$ height (Fig 1a). The bin was made by $10 \mathrm{~mm}$ thick acrylic sheet. The width and height of the soilbins were limited by the access space of the loading device, which is shown in Fig.(1a). After each test, the sand sample was loos ended by hand shovel then weighted and refilled the bin following the above procedure. This remolding method has a good repeatability that makes it possible to prepare the uniform sand samples of repeatable properties. Number of replication of each test was three times in order to minimize the scatter caused by the random non-homogeneity of the soil samples. Under normal conditions vehicles will sink into the terrain. Bekker developed an equation to determine this parameter. Bekker's equation can be rewrite as follow

$$
\begin{gathered}
\log (\mathrm{p})=\log (\mathrm{k})+\mathrm{n} \log (\mathrm{z}) \\
k=\frac{k_{c}}{b}+k_{\phi}
\end{gathered}
$$

The series of plate sinkage tests are carried out with different sized plates and $\log (\mathrm{p})$ is plotted against $\log (\mathrm{z})$. The series of straight lines are obtained as shown in figure (2). The parameter (n) is determined from the slope of these lines. The intercepts of the series lines in figure 2 express the value of $\log (\mathrm{k})$ ie $\log \left[\frac{k_{c}}{b}+k_{\phi}\right]$.plotting the intercepts $\mathrm{k}$ against $\frac{1}{b}$ 
for the three sinkage plates as shown in figure (3) the slop of these line express the parameter $\mathrm{k}_{\mathrm{c}}$. the intercept at $\frac{1}{b}=0$ express $\mathrm{k}_{\phi}$. This methods are repeated for all soil conditions and plate shapes.

\section{Determination of tire inflation pressure model}

The following relation is obtained to predict tire inflation pressure (Bekker, 1960):

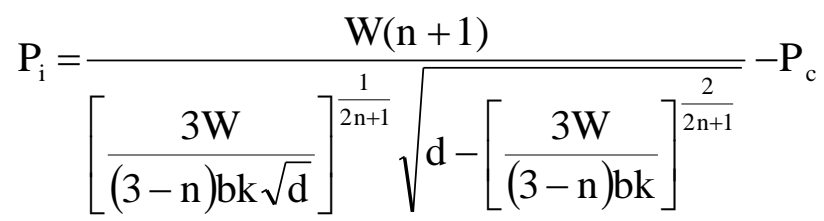

Where:

$$
\begin{aligned}
& \mathrm{P}_{\mathrm{i}}=\text { inflation pressure above which the tire, } \mathrm{kN} / \mathrm{m}^{2} \text {. } \\
& \mathrm{P}_{\mathrm{c}}=\text { contact pressure, } \mathrm{kN} / \mathrm{m}^{2} . \\
& \mathrm{W}=\text { track or wheel load, } \mathrm{kN} \\
& \mathrm{b}=\text { track or wheel width, } \mathrm{m} \\
& \mathrm{d}=\text { wheel diameter, } \mathrm{m} \\
& \mathrm{n}=\text { modulus expend } \\
& \mathrm{k}=\left(\frac{\mathrm{k}_{\mathrm{C}}}{\mathrm{b}}+\mathrm{k}_{\varphi}\right)
\end{aligned}
$$

\section{Determination contact pressure}

Dwyer (1984) recommends ground pressure index to be used as a tire characteristics as follow,

$$
\mathrm{P}_{\mathrm{c}}=\frac{\mathrm{W}}{\mathrm{b} \cdot \mathrm{d}} \cdot \sqrt{\frac{\mathrm{h}}{\delta}}\left(1+\frac{\mathrm{b}}{2 \cdot \mathrm{d}}\right)
$$

Where:

$\delta=0.2 \mathrm{~h}=$ tire defection, $\mathrm{m}$ (Dwyer1984)

\section{RESULTS AND DISCUSSION}

\section{Pressure- sinkage characterization for test plot}

The variables $\mathrm{k}_{\mathrm{c}}$ and $\mathrm{k}_{\phi}$ are modulus of soil deformation for cohesive and frictional components of soil strength and $n$ is the exponent of soil deformation. These three parameters are empirical quantities of the soil and can be readily found in soil property books. Bekker's equation 
indicates that the sinkage, $\mathrm{Z}$, is related to the width of the contact surface area. Larger values of $b$ lead to greater sinkage, $z$, for the same ground pressure.

All values for the different treatments under test are shown in Table (2)

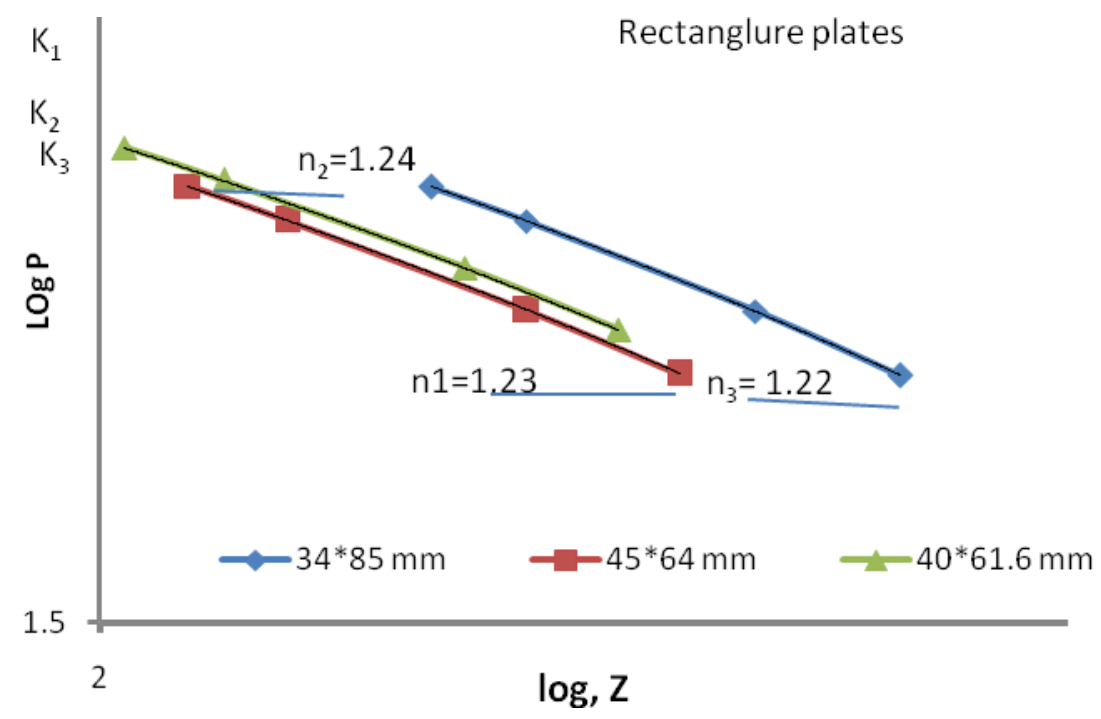

Fig. (2): Determination of parameters $k$ and $n$

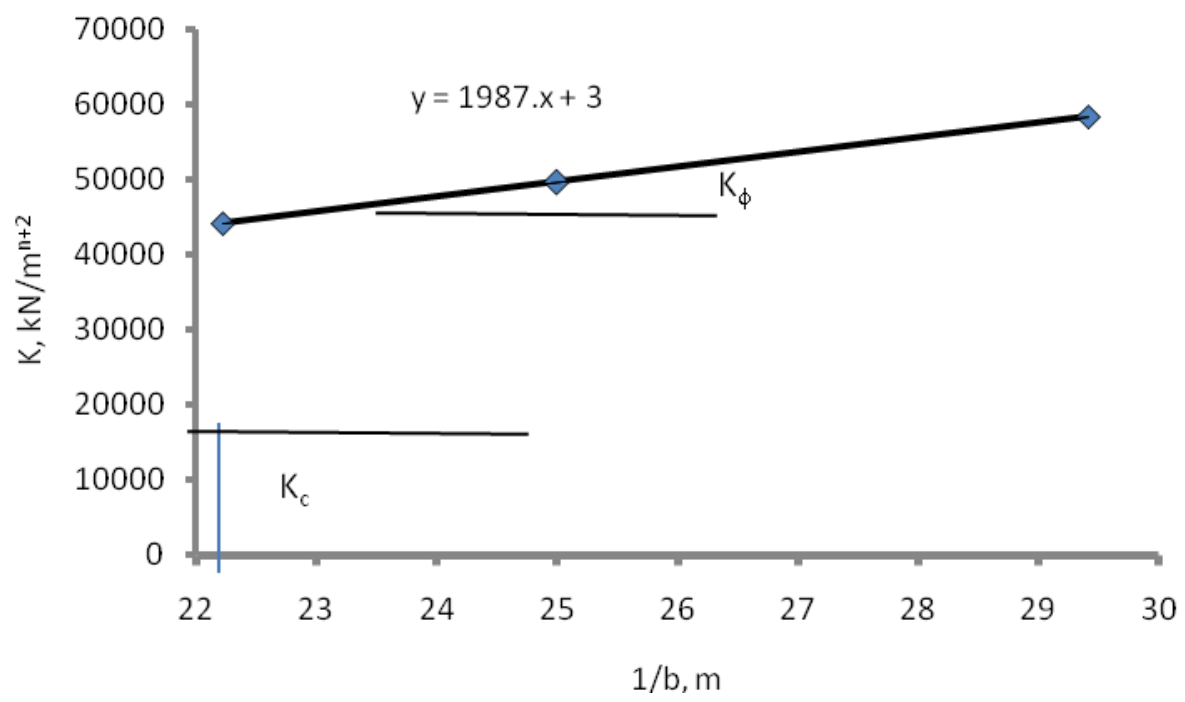

Fig (3): Determination of parameters $\mathrm{k}_{\mathrm{c}}$ and $\mathrm{k}_{\phi}$ 
Table (2): Bekker's constant and predicted tire inflation pressure at different soil conditions and sinkage plate shapes

\begin{tabular}{|c|c|c|c|c|c|c|c|c|c|c|}
\hline & \multicolumn{10}{|c|}{ Soil moisture content, $\%$} \\
\hline & \multicolumn{4}{|c|}{25} & \multirow{2}{*}{\multicolumn{3}{|c|}{$\frac{21}{\text { Soil bulk density, kg.m }{ }^{-3}}$}} & \multicolumn{3}{|c|}{18} \\
\hline \multirow{2}{*}{$\begin{array}{l}\text { Plate } \\
\text { shape }\end{array}$} & & \multicolumn{3}{|c|}{ Soil bulk density, kg.m ${ }^{-3}$} & & & & \multicolumn{3}{|c|}{ Soil bulk density, kg.m ${ }^{-3}$} \\
\hline & & 1200 & 1270 & 13159. & 1200 & 1270 & 13159. & 1200 & 1270 & 13159. \\
\hline \multirow{5}{*}{ 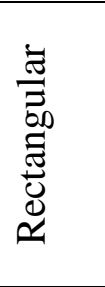 } & $\mathrm{k}_{\mathrm{c}}, \mathrm{kN} / \mathrm{m}^{\mathrm{n}+1}$ & 1912.95 & 1766.7 & 1053.78 & 1988.22 & 1754.415 & 1170.975 & 2299.83 & 1832.415 & 1210.17 \\
\hline & $\mathrm{k}_{\square}, \mathrm{kN} / \mathrm{m}^{\mathrm{n}+2}$ & 2 & 1 & -2 & 3 & 1.5 & -2.5 & 5 & 2 & -3 \\
\hline & $\mathrm{n}$ & 1.24 & 1.25 & 1.3 & 1.23 & 1.25 & 1.27 & 1.2 & 1.25 & 1.2 \\
\hline & $\mathrm{p}_{\mathrm{i}}, \mathrm{kN} / \mathrm{m}^{2}$ & 0.98 & 0.94 & 0.75 & 1.05 & 0.97 & 0.8 & 1.1 & 1 & 0.85 \\
\hline & $\mathrm{p}_{\mathrm{c}}, \mathrm{kN} / \mathrm{m}^{2}$ & 40.0693 & 40.0693 & 37.097 & 44.7989 & 35.8391 & 37.097 & 40.0693 & 35.8391 & 37.097 \\
\hline \multirow{5}{*}{ 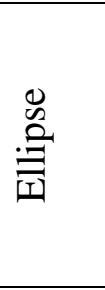 } & $\mathrm{k}_{\mathrm{c}}, \mathrm{kN} / \mathrm{m}^{\mathrm{n}+1}$ & 1912.17 & 1794.39 & 1054.17 & 2124.72 & 1599.39 & 1210.17 & 2179.12 & 1795.17 & 1268.86 \\
\hline & $\mathrm{k}_{\square}, \mathrm{kN} / \mathrm{m}^{\mathrm{n}+2}$ & 2 & -1 & -5 & 2 & -1.5 & -3 & 2.5 & -3 & -3.5 \\
\hline & $\mathrm{n}$ & 1.23 & 1.2 & 1.28 & 1.21 & 1.24 & 1.22 & 1.17 & 1.21 & 1.17 \\
\hline & $\mathrm{p}_{\mathrm{i}}, \mathrm{kN} / \mathrm{m}^{2}$ & 0.94 & 0.93 & 0.73 & 1.01 & 0.93 & 0.81 & 1.05 & 1.05 & 0.86 \\
\hline & $\mathrm{p}_{\mathrm{c}}, \mathrm{kN} / \mathrm{m}^{2}$ & 44.7989 & 32.7165 & 40.0693 & 36.5781 & 32.7165 & 40.0693 & 44.7989 & 32.7165 & 40.0693 \\
\hline \multirow{5}{*}{$\frac{0}{0}$} & $\mathrm{k}_{\mathrm{c}}, \mathrm{kN} / \mathrm{m}^{\mathrm{n}+1}$ & 17616.63 & 1682.85 & 1054.79 & 1948.83 & 1873.85 & 1274.09 & 1948.83 & 1717.56 & 1529.08 \\
\hline & $\mathrm{k}_{\square}, \mathrm{kN} / \mathrm{m}^{\mathrm{n}+2}$ & 3 & -5 & -3 & 4 & -4 & -4 & 4 & -4 & -6 \\
\hline & $\mathrm{n}$ & 1.25 & 1.15 & 1.53 & 1.23 & 1.17 & 1.4 & 1.2 & 1 & 1.37 \\
\hline & $\mathrm{p}_{\mathrm{i}}, \mathrm{kN} / \mathrm{m}^{2}$ & 0.89 & 0.902 & 0.71 & 0.95 & 0.93 & 0.82 & 1 & 1.06 & 0.89 \\
\hline & $\mathrm{p}_{\mathrm{c}}, \mathrm{kN} / \mathrm{m}^{2}$ & 40.0693 & 49.0747 & 32.4145 & 33.8648 & 37.097 & 32.4145 & 44.7989 & 49.0747 & 32.4145 \\
\hline
\end{tabular}




\section{Effect of soil moisture content on sinkage}

A reduction in soil moisture content (that is, changing from dry soil to wet soil) implies that tire sinkage gets extremely larger in the wet soil than in the dry soil The plate sinkage recorded the highest value at moisture content of $25 \%$ at the same dry bulk density of $1315 \mathrm{~kg} \cdot \mathrm{m}^{-3}$ Figure (4). The sink of plate increased as decreasing bulk density because the soil void ratio increased as bulk density decreased as shown in figure (5 and 6). Otherwise increasing soil moisture allow the plate to penetrate the soil easier than the lower moisture content, the moist soil help the soil layers to slide under the plate toward the plate edges.

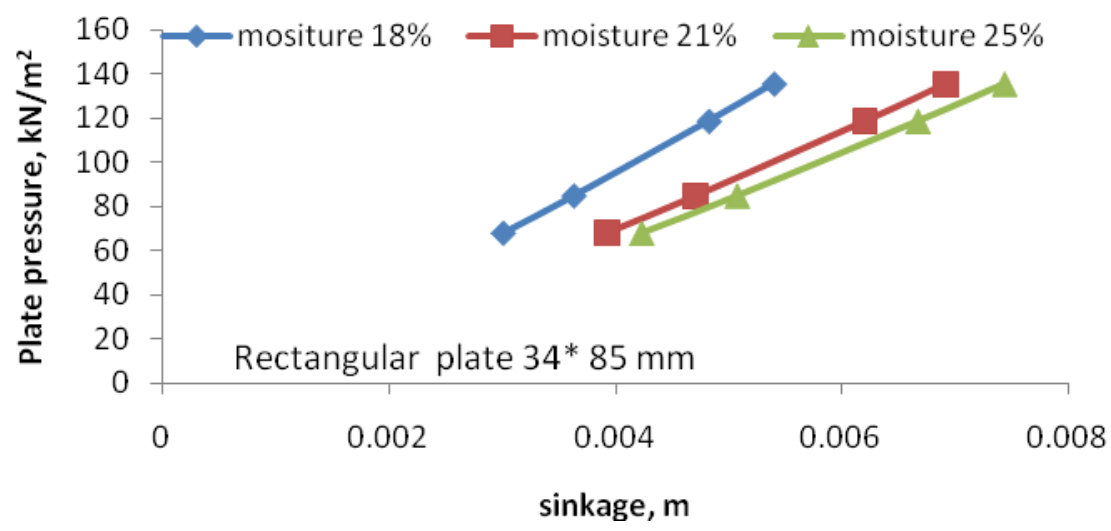

Fig.(4): Effect of pressure plate on plate sinkage at soil bulk density of $1315 \mathrm{~kg} . \mathrm{m}^{-3}$

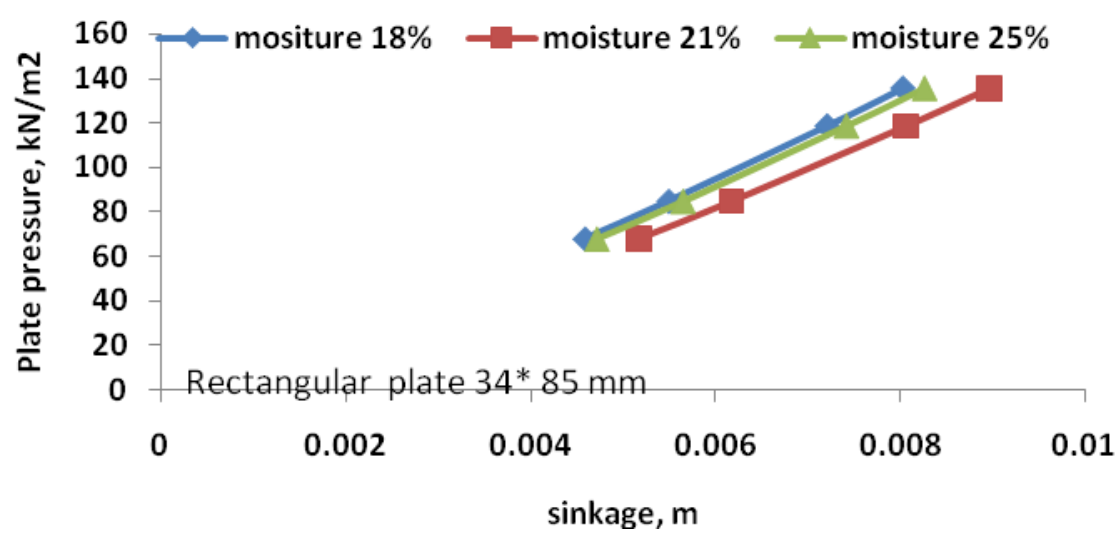

Fig.(5): Effect of pressure plate on plate sinkage at soil bulk density of $1270 \mathrm{~kg} . \mathrm{m}^{-3}$ 


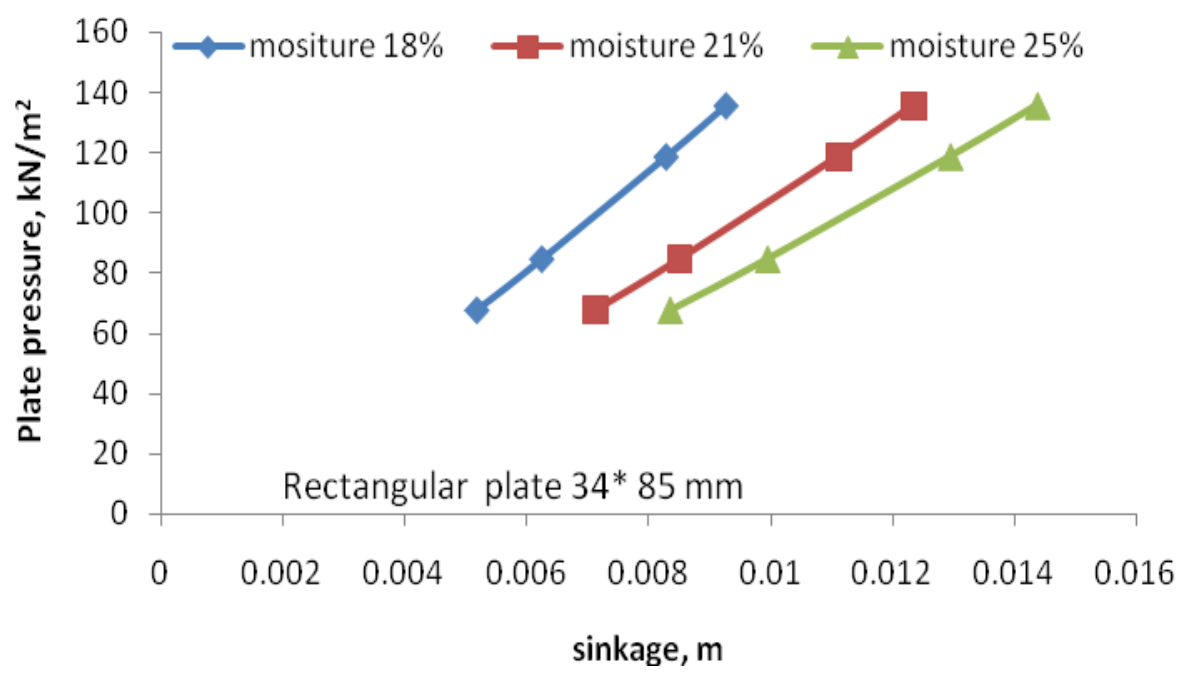

Fig.(6): Effect of pressure plate on plate sinkage at soil bulk density of $1200 \mathrm{~kg} . \mathrm{m}^{-3}$

\section{Effect of soil bulk density on sinkage}

A reduction in soil stiffness (that is, changing from dense soil to loose soil) implies that tire sinkage gets extremely larger in the loose soil than in the dense soil and the tire deflection clearly reduced. The lower soil bulk density and high moisture content of $25 \%$ recorded the greatest sinkage plate as shown in figure (7). The rat of plate penetration through the soil bulk density of $1315 \mathrm{~kg} \cdot \mathrm{m}^{-3}$ and $1270 \mathrm{~kg} \cdot \mathrm{m}^{-3}$ is much closer than its penetrate in the soil of bulk density of $1200 \mathrm{~kg} \cdot \mathrm{m}^{-3}$ this high penetration refer to the high void ratio in the low soil bulk density which gives chance to reduce this void as increasing in the load applied to sinkage plate, also as mentioned the high moisture content help the soil layers to escape to plate edges after the void between soil practical reached to the minimum value. On the lowest moisture content of $21 \%$ and $18 \%$ the effect on sinkage plate into the three soils with the different soil density with the same behavior but with the less rate in sink of the plate into the soil than $25 \%$ soil moisture content as shown in figure $\mathrm{s}(8$ and 9). 


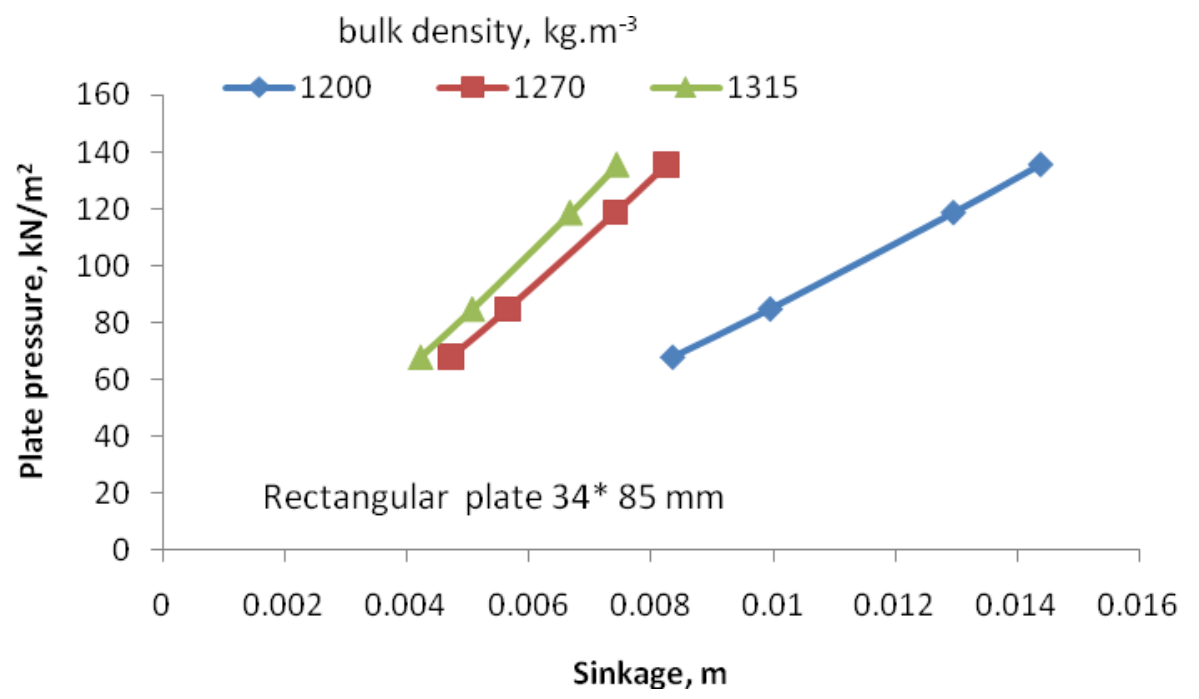

Fig.(7): Effect of pressure plate on plate sinkage at soil moisture content of $25 \%$ bulk density, $\mathrm{kg} \cdot \mathrm{m}^{-3}$

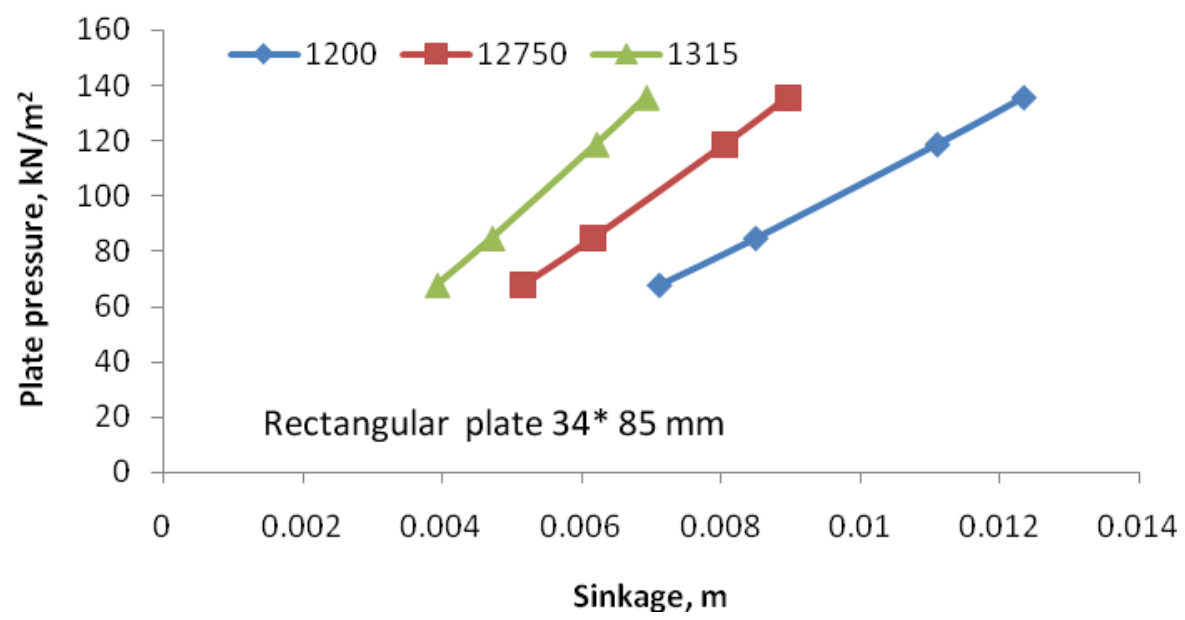

Fig.(8): Effect of pressure plate on plate sinkage at soil moisture content of $21 \%$

Effect of soil bulk density and moisture content on tire inflation pressure

The predicted tire inflation pressure for Helwan 35-IMT at different sandy soil conditions is shown in figures $(10,11$ and 12). The inflation pressure is derived from equation 5 according to Bekker's constants obtained from the three plate shape. In general the tire inflation pressure increased as increasing soil bulk density due to increasing soil bearing capacity. Decreasing tire inflation pressure is desired as increasing soil 
moisture content. Tire inflation pressure at dry soil bulk density of 1270 $\mathrm{kg} / \mathrm{m}^{3}$ for soil moisture content of $21 \%$ and $25 \%$ are very closed and can be neglected while predicted tire inflation pressured from ellipse and circle plates at soil moisture content of $18 \%$ is higher. The changes in inflation pressure using rectangular plate are changing with constant rate as shown in figure (10). So using the rectangular plate to determined Bekker's constants is more realistic than the other plate shapes.

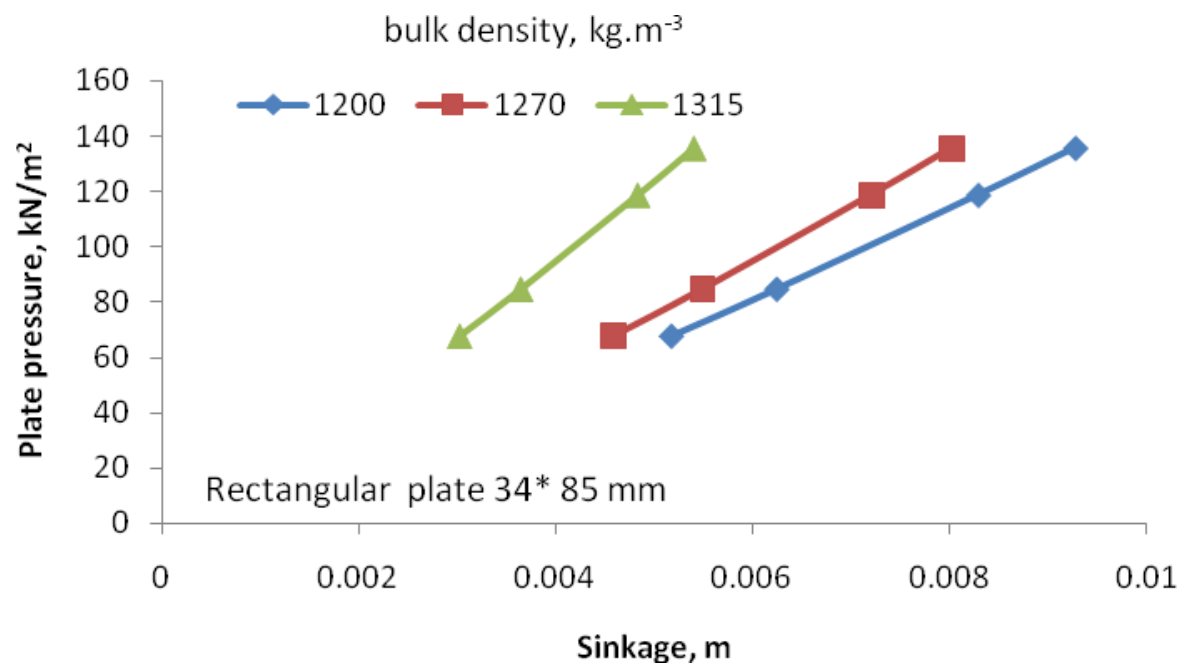

Fig.(9): Effect of pressure plate on plate sinkage at soil moisture content of $18 \%$ - $18 \% \square 21 \% \square 25 \%$

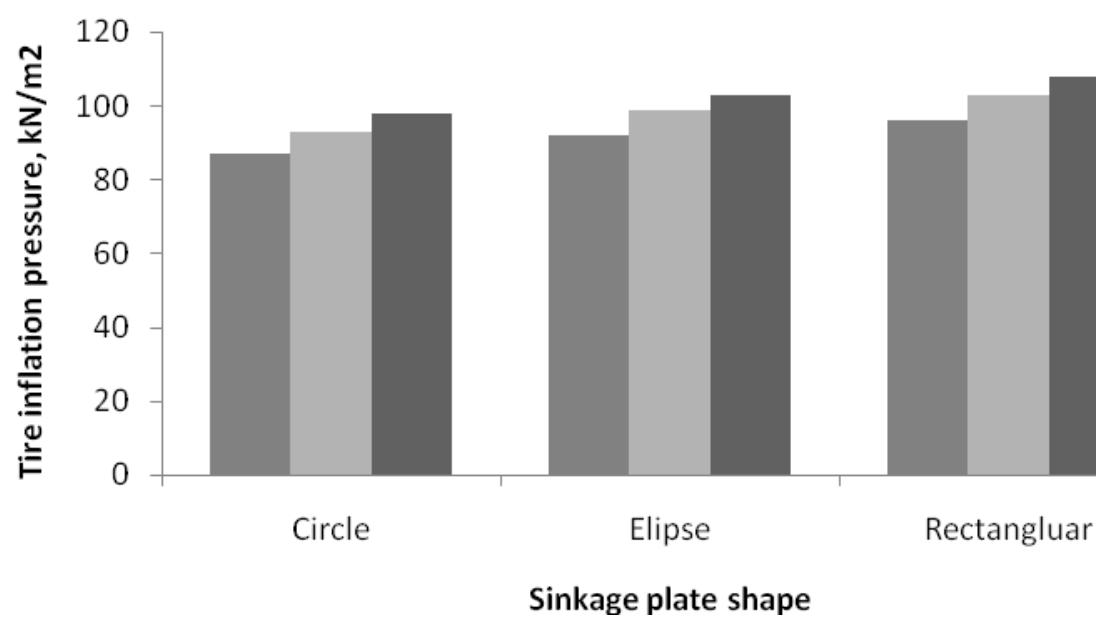

Fig, (10): Effect of moisture content on tire inflation pressure at soil bulk density of $1200 \mathrm{~kg} \cdot \mathrm{m}^{-3}$. 


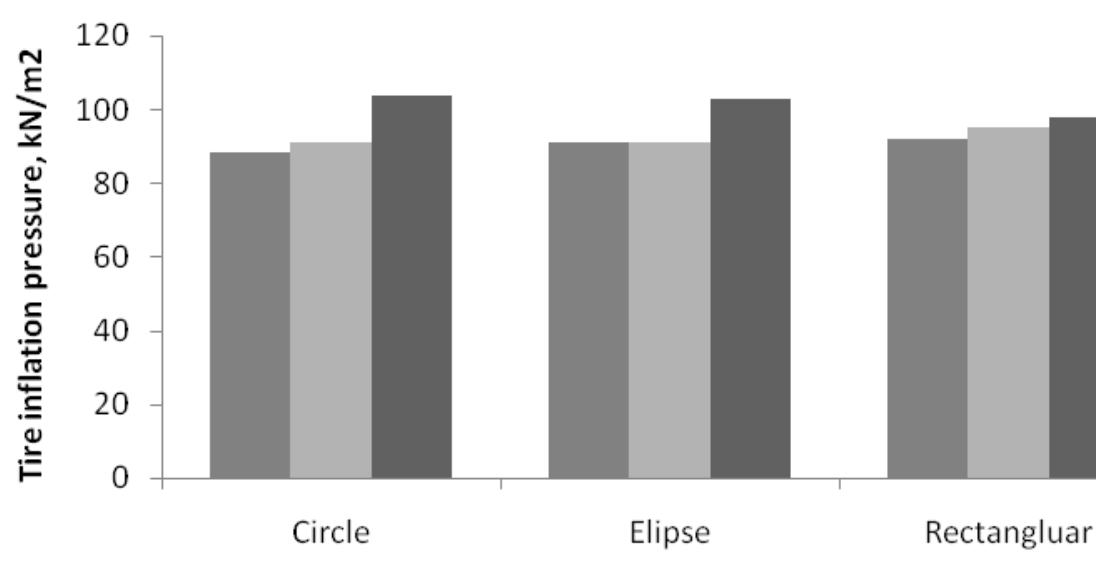

Sinkage plate shape

Fig, (11):Effect of moisture content on tire inflation pressure at soil bulk density of $1270 \mathrm{~kg} \cdot \mathrm{m}^{-3}$.

$$
\text { - } 18 \%-21 \%-25 \%
$$

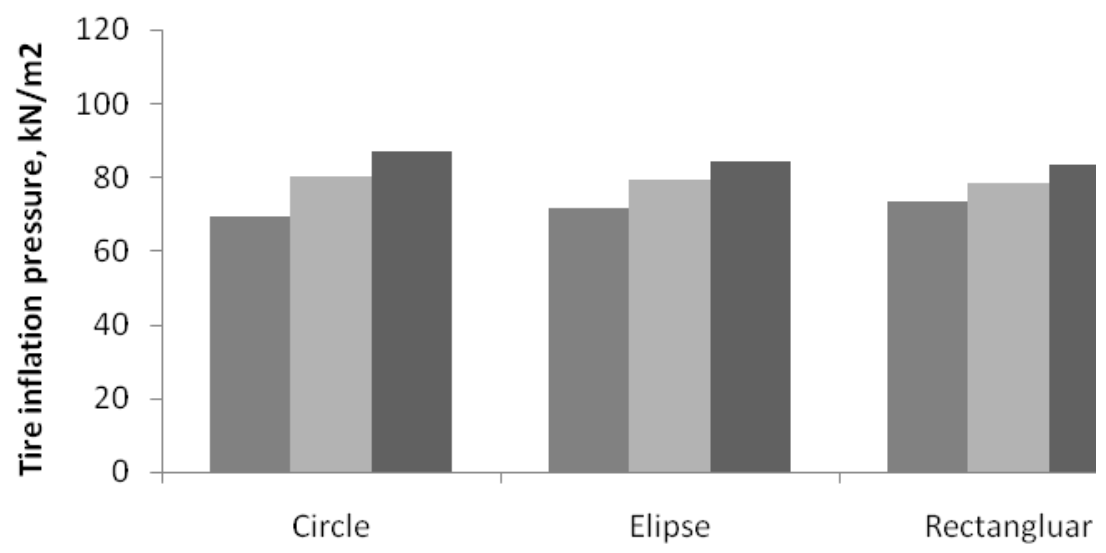

Sinkage plate shape

Fig, (12): Effect of moisture content on tire inflation pressure at soil bulk density of $1315 \mathrm{~kg} \cdot \mathrm{m}^{-3}$.

\section{CONCLUSION}

The results of laboratory trials show that the used experimental device together with the experimental methodology is suitable for measuring the sinkage parameters of loose dry sand in relation to vehicle mobility in the Bekker's pressure-sinkage equation. The difference between the values of $\mathrm{k}_{\mathrm{c}}, \mathrm{k}_{\phi}$, and $\mathrm{n}$ obtained from sinkage test with ellipse plates and those 
obtained with rectangular plates is practically negligible but is high with circle plate. It means that the values of $\mathrm{k}_{\mathrm{c}}, \mathrm{k}_{\phi}$ and $\mathrm{n}$ determined in tests with ellipse plates and with rectangular plates in loose dry sand can be used to evaluate the performance of off-road vehicles with ground contact areas reliability of soil sinkage prediction. The obtained results also reveal to the following:

1. Predicted tire inflation pressure decreased with increasing soil moisture content

2. A reduction in soil stiffness (that is, changing from dense soil to loose soil) implies that tire sinkage gets extremely larger in the loose soil than in the dense soil and the tire deflection clearly reduced

3. Rectangular plate shape gives a good prediction for tire inflation pressure than circle and ellipse plate shapes.

\section{REFERENCES}

Abu-Hamdeh, N. H and R. C. Reeder (2003). Measuring and predicting stress distribution under tractive devices in undisturbed soil. Biosys. Eng., 85: 493-502.

Bahnasy, A.M.F. (2004). Predicting rolling resistance for tractors using soil property. Modern Technology in Agric. Eng. Research and Application, th $12^{\text {th }}$ Annual Conference of Misr Society of Agric. Eng., 4-5 October 2004.

Bekker, M. G. (1960). Off- the-road locomotion Ann Arbor University of Michigan Press, PP200

Bekker, M. G. (1969).Introduction to terrain-vehical systems. Ann Arbor University of Michigan Press, PP820.

Botero, O. and P.H. Gotteland (2005). Modelling of sinkage tests in tilled soils for mobility study. Soil and Tillage Research, 80(1-2):215231.

Benoit O, Gotteland PH (2006). Sinkage Tests for Mobility Study, Modeling and Experimental Validation. J. Terramechanics, 43: 451- 467.

Brooks CA, K, Iagnemma (2005). Vibration-Based Terrain Classification for Planetary Exploration Rovers, IEEE Trans. On Robotics,

Dwyer, M.J. (1984). Tractive performance of wheeled vehicles. Journal of Terramechanics 21(1):19-34. 
Defossez, P and Richard (2002). Models of soil compaction due totraffic and their evaluation. Soil till. Res. 67:41-64

Gee-Clough. D. 1978. A comparison of the mobility number and Bekker approaches to the traction mechanics and recent advances in both methods at the N.I.A.E. Proceedings of the 6th International ISTVS conference, Vienna, Austria, August 22-25, 1978. II:735-755.

Rashidi, M., A. Keyhani and A. Trabatabaeefar (2006). Muliplate penetration test to predict soil pressure sinkage. Int. J. Agri. Biol., Vol. 8 (1) PP: 1:9

Lee, D.R. and K.U. Kim (1977). Effect of inflation pressure on tractive performance of bias tires. Journal of terramechamics 34(3):187208.

Kaje L. 1968. Terrain trafficability. Helsinki. 53 p.

McKyes, E. and Fan, T. (1985). Multiplate penetration tests to determine soil stiffness moduli. Journal of Terramechanics, 22, 157-162.

McKyes, E. (1985). Soil cutting andtillage. Elsevier, pp. 160

Maclaurin, E.B (1990). The use of mobility nimefs to describe the in field tractive performance of pneumatic tires. Proceedings of the $10^{\text {th }}$ International ISTvS Conference. Kobe. Japan August 20-24, 1990 PP: 177-186.

Mohamed, A.A.I (2007). Evaluation of different methods for estimating the rolling resistance of agricultural tractors based on bekker's soil parameters. Journal of Agricultural Sciences Mansoura University. Volume 32 No. (8) : 6329-6346

Pope RG (1969). The Effect of Sinkage Rate on Pressure Sinkage Relationship and Rolling Resistance in Real and Artificial Clays. J. Terramechanics, 6: 31-38.

Reece, A.R. (1964). Curve fitting technique in soil vehicle mechanics. Journal of Terramechanics, 1, 44-55.

Saarilahti, M., (1997a). Suitability of mobility models for evaluating environmental effects of terrain transport. Proceedings of the 7 th ISTVS European Conference, Ferrara, Italy 8-10.10.1997: 425-432. Wong, J. Y. (1980). Data processing methodology in the characterization of the mechanical properties of terrain. Journal of Terramechanics, $17,13-41$. 
Wong JY (2001). Theory of Ground Vehicles, 3rd Edition, Wiley, New York.

Wismer, R. D. \& Luth, H. J. 1973. Off-road traction prediction for wheeled vehicles. Transaction ASAE 17(1):8-10,14.

$\mathrm{Yu}, \mathrm{T}$. (2005). The tractive performance of afriction-based prototype track. Ph.D Thesis, Civil and Biosystsems Eng. Dept., University of Pretoria, South Africa.

Zadeh, S.R.A. (2006). Modeling of energy requirements by a narrow tillage tool. PhD Thesis, Dept. of agri. And Bioresource Eng. Univ. of Saskstchewan, Sakatoon, Canada: 190p.

\section{الملخص العربي}

\section{استخدام الوح مختلفة الابعاد والاثكال للتنبؤ بمقدار غوص وضغط عجل الجرار تحت ظروف مختلفة للتربة \\ احمد محمد فوزى بهنسى الخد}

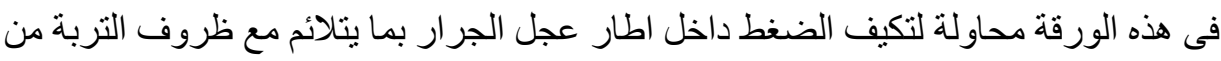

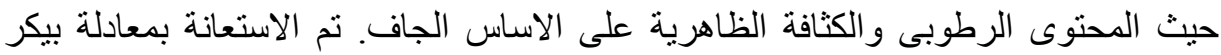

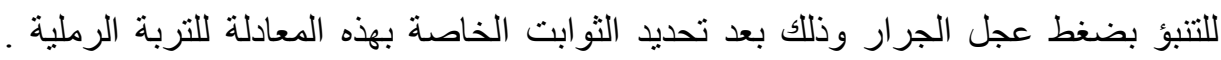

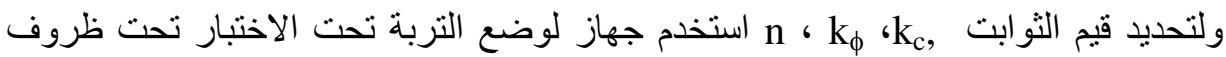

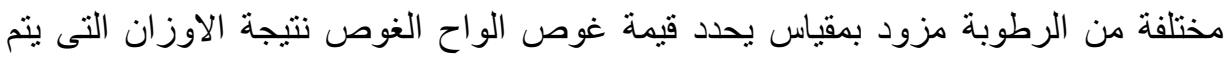

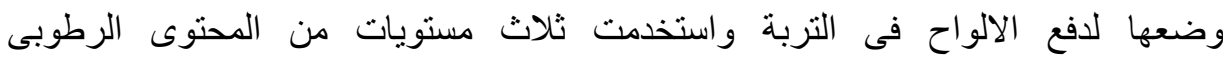

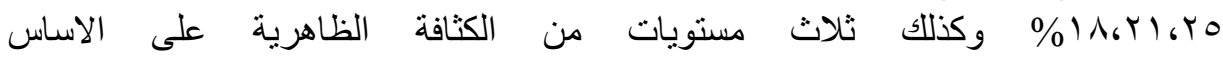

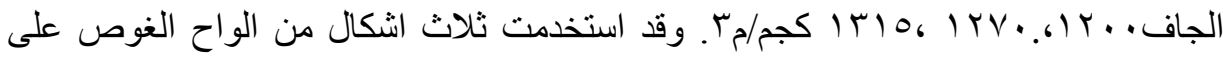

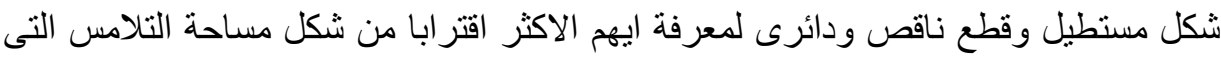

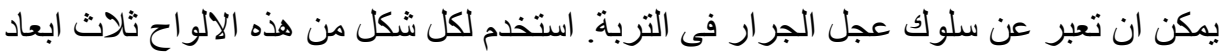

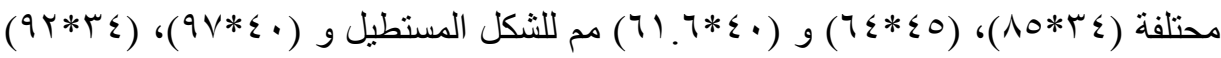

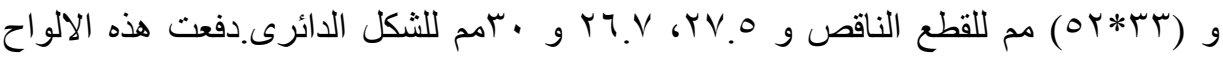

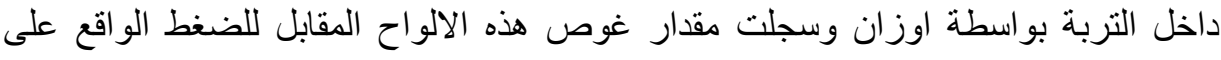

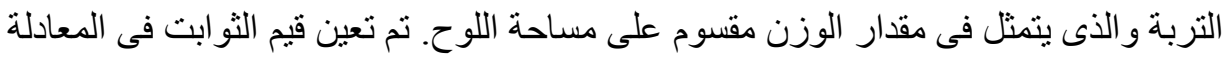

$$
P=\left(\frac{k_{c}}{b}+k_{\varphi}\right) Z^{n}
$$

• باحث اول معهز بحوث الهندسة الزراعية 


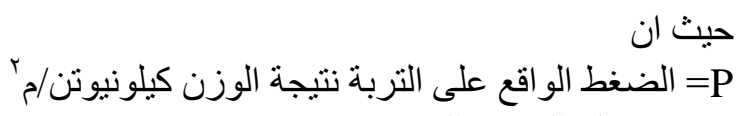

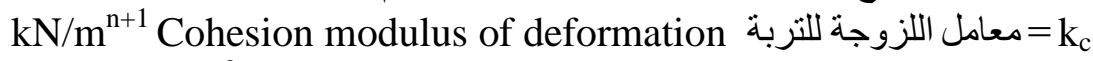
$\mathrm{kN} / \mathrm{m}^{\mathrm{n}+2}$ Friction modulus of deformation معامل الاحتكاحلى $=k_{\phi}$

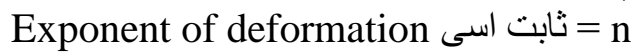

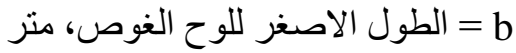

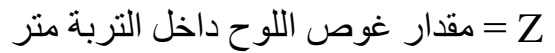

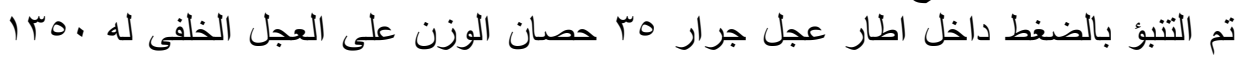

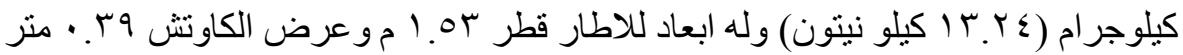

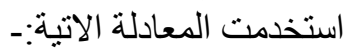

$$
P_{i}=\frac{W(n+1)}{\left[\frac{3 W}{(3-n) b k \sqrt{d}}\right]^{\frac{1}{2 n+1}} \sqrt{d-\left[\frac{3 W}{(3-n) b k}\right]^{\frac{2}{2 n+1}}}}-P_{c}
$$

P = Pi

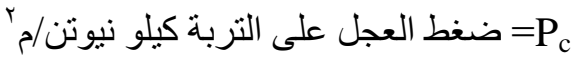

$$
\left(\frac{\mathrm{k}_{\mathrm{C}}}{\mathrm{b}}+\mathrm{k}_{\varphi}\right)=\mathrm{K}
$$

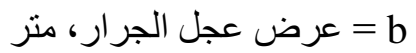

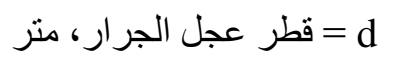

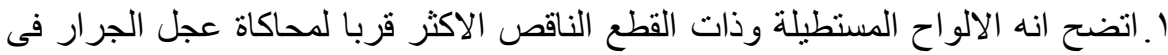

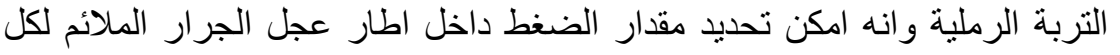
ظرف من ظروف التربة المختلفة.

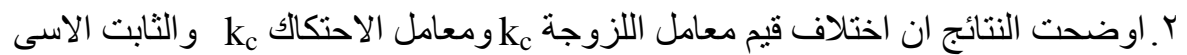

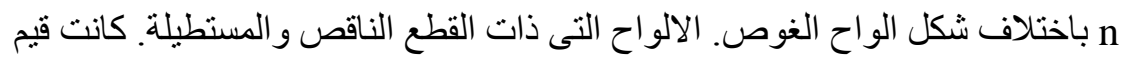

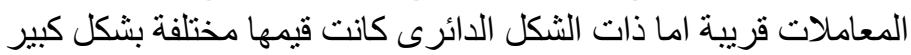

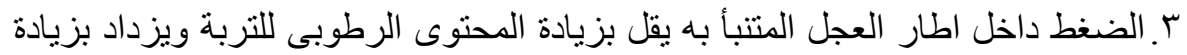
الكثافة الظاهرية للتربة. ع.اختلاف الكثافة الظاهرية يؤدنالى غوص اكبر لعجل الجالة الجرار فى التربة ذات كثافة

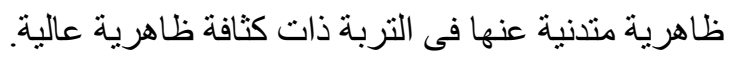

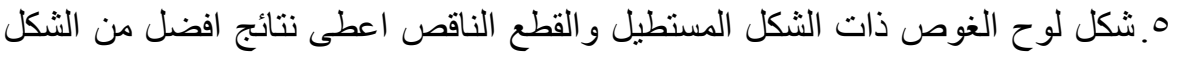

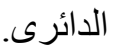
T.تتراوح قيم المعامل الاسى لمعادلة بيكر بين الى سهـ التبعا لتغير ظروف التربة

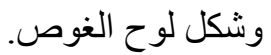

